Gulawentah: Jurnal Studi Sosial

ISSN 2528-6293 (Print); ISSN 2528-6871 (Online)

Vol. 3, No. 2, Desember 2018, hal 113-119

Tersedia Online: http://e-journal.unipma.ac.id/index.php/gulawentah

\title{
Upacara Adat Wisuda Waranggono di Kayangan Api Desa Sendangharjo Kecamatan Ngasem Kabupaten Bojonegoro (Nilai Budaya dan Potensinya Sebagai Sumber Pembelajaran Sejarah)
}

\author{
Vera Martina Dewi \\ Program Studi Magister PIPS, Universitas PGRI Madiun, Indonesia \\ Email: veradewi10@gmail.com
}

\begin{abstract}
Abstrak
Penelitian ini bertujuan untuk mengetahui latar belakang prosesi, nilai budaya yang terkandung dan nilai budaya yang dapat dijadikan sebagai sumber pembelajaran sejarah pada upacara adat wisuda waranggono. Penelitian ini menggunakan pendekatan kualitatif. Sumber data yang digunakan dalam penelitian ini yaitu sumber data primer dan sumber data sekunder. Teknik pengumpulan data menggunakan teknik wawancara, observasi dan dokumentasi. Sedangkan analisis data menggunakan teknik Coding Model Strauss dan Corbin. Hasil penelitian yang diperoleh yaitu Sebelum upacara dimulai para waranggono harus puasa dan juga mengikuti ritual siraman. Upacara adat wisuda waranggono dilakukan pada bulan syuro dan membutuhkan piranti gong lengkap dan menggunakan lagu mukdi rahayu dan ibu pertiwi. Nilai budaya yang terkandung dalam upacara adat wisuda waranggono adalah nilai religius, gotong royong, estetika, dan juga nilai kebersamaan. Upacara adat wisuda waranggono ini mempunya potensi sebagai sumber pembelajaran sejarah yakni sebagai materi tambahan dalam pembelajaran mata pelajaran sejarah di SMA kelas X semester I, dengan Standart Kompetensi Memahami prinsip dasar ilmu sejarah dengan Kompetensi Dasar Mendeskripsikan tradisi sejarah dalam masyarakat Indonesia masa pra-aksara dan masa aksara.
\end{abstract}

Kata kunci: nilai budaya; sumber pembelajaran sejarah; wisuda Waranggono

\section{The Effect of Using Traditional Game "Gobak Sodor” on Social Attitudes of the Third Grade Students, SDN 01 Manguharjo, Madiun}

\begin{abstract}
The purpose of this research is to know the background of the procession, culture values, and the values of the culture can make the source of history learning at the tradition ceremony waranggono. This research uses a qualitative approach. The source of the data this research uses primary and secondary data. The technique of data collection consists of interviews, observation, and documentation. Whereas, the data analyses using the techniques of Coding Model of Strauss and Corbin. The result of the research is before the ceremony started the waranggono should do of fasting and follow the ritual of bathing. Waranggono tradition ceremony was conducted on the mont of syuro was requires the complete gong and used the song mukdi rahayu and Ibu pertiwi. Waranggono tradition ceremony contained of culture values there are religious value,mutual cooperation, aesthetics, and also the value of togetherness. The potential in waranggono tradition ceremony as a source of history learning as a dditional material in learning subjects in high school history class X semester I, with a Standard of competence to understand the basic principles of the science of history with The basic competency Describes the tradition of history in Indonesia Society pre-revised and the revised.
\end{abstract}

Keywords: cultures; source of history learning; waranggono.

DOI: 10.25273/gulawentah.v3i2.3464

Copyright (C) 2018 Universitas PGRI Madiun

All rights reserved. 


\section{Pendahuluan}

Indonesia merupakan negara yang sangat kaya akan kebudayaan, kesenian, budaya, suku, tradisi dan upacara adat. Mulai dari sabang sampai Merauke memiliki keunikan tersendiri dalam hal kebudayaan ataupun yang lainnya. Seperti halnya Jawa Timur mempunyai banyak sekali upacara adat atau kesenian yang sudah dikenal oleh masyarakat daerah, luar daerah, bahkan telah mendunia. Kebudyaan yang ada di Indonesia sangat beragam, banyak ilmuwan yang berpendapat tentang arti dari kebudayaan, salah satunya adalah Koentjaraningrat yang mengungkapkan bahwa kebudayaan berasal dari suatu kebiasaan dan tata kelakuan sehari-hari dan membentuk menjadi sebuah kebiasaan dari masyarkat itu sendiri. Kebudayaan juga bisa tercipta karena adanya campur tangan dari manusia. Manusia merupakan makhluk yang berbudaya, melalui akalnya manusia dapat mengembalikan kebudayaan.

Begitu pula manusia hidup dan tergantung pada kebudayaan dan hasil ciptaannya, kebudayaan juga bisa memberikan aturan bagi manusia dalam mengolah lingkungan dengan teknologi hasil ciptaannya (Setiadi dkk, 2007:37-38). Koentjaraningrat berpendapat bahwa ada tujuh unsur kebudayaan yang dapat ditemukan pada semua bangsa di dunia. Ketujuh unsur yang dapat kita sebut sebagai isi pokok dari tiap kebudayaan di dunia itu adalah, bahasa, sistem pengetahuan, organisasi sosial, sistem peralatan hidup dan teknologi, sistem mata pencaharian hidup, sistem religi, dan kesenian (Koentjaraningrat, 2009).

Upacara adat merupakan tingkah laku resmi yang dilakukan untuk peristiwa-peristiwa yang dapat ditunjukkan pada kegiatan sehari-hari yang berkembang di masyarakat secara turun temurun. Upacara adat dilaksanakan saat hendak melakukan kegiatan ritual, kebanyakan masyarakat desa lah yang masih mempercayai dan melaksanakan upacara adat. Mereka percaya jika mereka masih melaksanakan upacara adat maka terdapat berkah tersendiri setelah melakukan upacara tersebut. Upacara adat yang ada di Kabupaten Bojonegoro adalah upacara adat wisuda waranggono yang dilaksanakan di Kayangan api. Banyak ritual dan juga prosesi yang unik pada kegiatan upacara adat wisuda waranggono. Upacara ini menyita perhatian banyak orang dan menjadi daya tarik wisata namun tidak banyak warga Bojonegoro yang mengerti dan memahami tentang prosesi dan juga nilai budaya yang ada pada upacara adat wisuda waranggono. Selain itu nilai-nilai upacara adat wisuda waranggono juga tersebut juga dapat dijadikan sebagai sumber pembelajaran sejarah oleh guru sejarah yang ada di Kabupaten Bojonegoro. Dengan adanya penelitian ini diharapkan masyarakat Bojonegoro mengerti dan memahami tentang prosesi, nilai budaya dan juga nilai budaya yang dapat dijadikan guru sebagai sumber pembelajaran sejarah.

Upacara tradisioanl adalah salah satu wujud warisan kebudayaan. Kebudayaan merupakan warisan sosial yang hanya bisa dimiliki oleh masyarakat yang mendukungnya dengan cara mempelajarinya. Terdapat cara-cara atau metode tertentu dalam tiap masyarakat untuk memaksa tiap warganya mempelajari kebudayaan yang di dalamnya terdapat norma-norma atau nilai-nilai kehidupan yang berlaku dalam tata pergaulan masyarakat yang bersangkutan. Menaati norma dan mengangkat nilai-nilai menurut warga sangat penting demi kelestarian hidup bermasyarakat (Purwadi,2005:1). Upacara adat tradisional Jawa merupakan perwujudan dari setiap tingkah laku masyarakat yang menjadi suatu kebiasaan dan telah turun temurun. Dalam setiap kegiatannya pasti mempunyai nilai-nilai, arti dan kegunaan yang terkandung di dalamnya yang dapat dijadikan sebagai kebudayaan nasional. Upacara tradisional ini bersifat sakral dan religius, sehingga dalam setiap kegiatannya pasti ada maksud dan harapan yang ingin diraih.

Waranggono menurut Herawati (2009:93) adalah pesinden atau swarawati, ada juga yang menyebutkan ledhek. Waranggono berasal dari kata "wara" dan "anggana". Wara adalah sebutan untuk perempuan sedangkan anggana adalah sendiri. Dalam setiap pertunjukan wayang selalu ada yang melantunkan tembang (lagu-lagu tradisional). Orang tersebut disebut Pesinden. Setiap pertunjukan diiringi beberapa pesinden sesuai kebutuhan. Pesinden melantunkan tembang sejak saat pertunjukan akan dimulai sampai pertunjukan selesai. Pada adegan-adegan tertentu dilantunkan tembang-tembang tradisional yang syahdu dan pada saat-saat yang lain mereka melantunkan 
tembang-tembang dolanan yang bernada riang (Lisbijanto, 2013:20). Untuk menjadi seorang waranggono tidaklah mudah, seorang waranggono harus melakukan beberapa prosesi. Prosesinya yaitu seorang waranggono harus menyiapkan beberapa persyaratan untuk mengikuti prosesi, seperti menyiapkan kembang tujuh rupa yang digunakan saat menari mengelilingi Kayangan Api, setelah itu seorang waranggono harus menyiapkan pakaian seperti yang digunakan pada waktu menyinden. Menurut pendapat Herawati (2009:94) seorang pesinden tidak hanya mempunyai suara yang merdu, namun harus menguasai beberapa hal, antara lain: (a) Paham tentang irama, maksudnya dalam menyinden harus dapat menyesuaikan dengan irama yang ditabuh pangrawit, (b) Paham tentang laras, maksudnya dengan memahami tentang laras baik laras barang maupun slendro seorang waranggono dalam menyanyikan tembang tidak akan flas atau blero, dan (c) Paham bentuk-bentuk gending, antara lain : ketawang, gending ladrang, gending lancaran, dan gending kethuk kalih.

Nilai budaya merupakan suatu konsepsi-konsepsi yang telah hidup dalam alam penalaran separuh masyarakat tentang suatu hal yang dianggap sangat mulia, menurut pendapat Koentjaraningrat (Hanif, 2016). Uhi (dalam Hanif,2016) juga mengungkapkan bahwa nilai budaya adalah konsepsi umum yang terorganisir dan dapat mempengaruhi perilaku manusia dalam hubungannya dengan lingkungan alam dan sosial, serta dengan sang maha pencipta. Nilai budaya tersebut menurut Kluckhohn (dalam Koetjaraningrat, 2016: 156) dibangun ke dalam suatu sistem nilai budaya yang berupa pandangan hidup (word view) bagi manusia penganutnya dan berfungsi sebagai pedoman bagi sikap mental, cara berpikir, dan bertingkah laku. Nilai budaya memberikan penegasan jika sistem nilai budaya merupakan kesatuan unsur-unsur yang membentuk konsepsi pemikiran dan perilaku manusia dalam masyarakat.

Proses pembelajaran sejarah yang bagus ialah proses pembelajaran yang dapat memunculkan kemampuan peserta didik dalam melaksanakan konstruksi kondisi sekarang dengan menghubungkan atau melihat masa lampau yang menjadikan basis topik pembelajaran sejarah. Keahlian melaksanakan konstruksi ini harus dikemukakan secara kuat agar pembelajaran tidak terjerumus dalam pembelajaran yang bersifat konservatif. Kontekstualitas sejarah harus kuat mengemuka dan berbasis pada pengalaman pribadi para peserta didik. Sedangkan sejarah tidak dapat terlepas oleh konsep perubahan, kontinyuitas dan waktu (Subakti, 2010:67). Untuk itu diperlukan berbagai sumber pembelajarannya. Sumber pembelajaran menurut Kochhar (2008) merupakan sarana pembelajaran dan pengajaran yang begitu dibutuhkan. Sudah menjadi kewajiban untuk pendidik agar memanfaatkan berbagai macam sumber supaya memperoleh alat bantu yang tepat sasaran untuk menyampaikan materi dan melengkapi apa yang sudah disediakan di buku cetak, untuk menciptakan minat dari peserta didik, untuk memperluas konsep, dan untuk menambah informasi.

\section{Metode Penelitian}

Penelitian ini menggunakan pendekatan kualitatif deskriptif. Penelitian dilaksanakan mulai bulan Maret sampai dengan Agustus 2018. Tempat penelitian di Kabupaten Bojonegoro tepatnya di Kayangan api Desa Sendangharjo Kecamatan Ngasem.

Sumber data yang digunakan bersifat primer dan sekunder. Teknik pengambilan datanya menggunakan wawancara, observasi, dan pencatatan dokumen. Alat utama pengambilan datanya yaitu peneliti sendiri. Sedangkan alat bantunya berupa alat pencatat dan rekam. Data dianalisis dengan teknik koding Model Strauss dan Corbin (2009) yang terdiri dari tiga jenis pengodean (coding); pengodean terbuka (open coding), pengodean selektif (selective coding), Tahap pengodean terpilih merupakan tahap analisis data yang mengacu pada proses strukturisasi, sistemasi dan penentuan ulang dalam kegiatan story-line sebagai kelanjutan dari tahap pengodean terpusat.

\section{Hasil dan Pembasan}

Upacara adat wisuda waranggono adalah salah satu upacara adat yang ada di Kabupaten Bojonegoro, upacara tersebut adalah upacara pelantikan sinden yang dilakukan di Wisata Kayangan 
Api Desa Sendangharjo Kecamatan Ngasem Kabupaten Bojonegoro. Upacara adat wisuda waranggono sudah biasa dilakukan oleh waranggono sebelum mereka sah menjadi seorang sinden. Diberbagai daerah orang menyebut waranggono dengan sebutan yang berbeda-beda, ada yang menyebutnya sinden, sindir, dan juga ledhek. Istilah waranggono muncul karena kebiasaan masyarakat dahulu yang sangat menyukai hiburan tari-tarian. Dipilihnya wisata Kayangan Api sebagai tempat pelaksanaan juga terdapat alasan tersendiri, karena pada zaman dahulu terdapat pande besi yaitu Eyang Kriyo Kusumo beserta putrinya yang bertempat di Wisata Kayangan Api sangat menyukai kesenian tayub atau yang berbau musik Jawa dan tari-tarian Jawa.

Sebelum mengikuti upacara adat wisuda waranggono, seorang waranggono harus mengikuti beberapa persyaratan yang telah ditentukan, waranggono harus melakukan puasa satu hari satu malam, harus mengikuti siraman disertai dengan doa. Hal tersebut dipercaya agar prosesi upacara adat wisuda waranggono dapat berjalan dengan lancar. Setelah waranggono melakukan persyaratan tersebut waranggono juga harus menyiapkan pakaian yang bagus dan riasan wajah sehingga dalam prosesi nanti waranggono akan terlihat menarik. Selain itu seorang waranggono harus menyiapkan bunga tujuh rupa dan juga dupa tempat bunga yang nantinya akan digunakan waranggono dan ditaburkan ke dalam bara api saat prosesi upacara adat wisuda waranggono berlangsung. Pada zaman dulu seorang waranggono yang akan disahkan adalah umur 40 tahun namun seiring zaman yang semakin modern anak-anak yang ingin menjadi seorang waranggono juga sudah bisa mengikuti upacara ini. Selain perlengkapan di atas jika waranggono ingin mengikuti upacara adat wisuda waranggono juga sudah harus hafal lagu sekelas asmorondono dan sudah bisa menari gambyong parianom.

Pelaksanaan upacara adat wisuda waranggono dilaksanakan pada waktu bulan syuro, dipilihnya bulan syuro karena pada umumnya masyarakat Jawa percaya bahwa syuro adalah bulan yang sakral. Selain itu dalam prosesi upacara adat wisuda waranggono juga membutuhkan piranti pendukung seperti musik dan juga gong gamelan, musik yang mengiringi dalam pelaksanakan upacara adat wisuda waranggono adalah jenis musik gamelan dan lagu yang mengiringi adalah lagu mukdi rahayu dan juga ibu pertiwi, dipilihnya musik-musik Jawa tentu mempunyai maksud dan tujuan tersendiriyaitu agar prosesi upacara adat wisuda waranggono terlihat sakral dan lebih menghayati selain itu waranggono juga beraharap dalam prosesi upacara adat wisuda waranggono Eyang Kriyo Kusumo dapat hadir ikut serta dalam upacara tersebut.

Upacara adat wisuda waranggono sudah ada sejak dulu,upacara ini sudah ada sejak zaman nenek moyang dan dipercayai oleh masyarakat dan juga waranggono yang ingin disahkan. Setelah semua persyaratan sudah dilakukan oleh waranggono, seorang waranggono juga harus menyiapkan mental karena mereka harus menari mengelilingi bara api yang ada di wisata Kayangan Api.

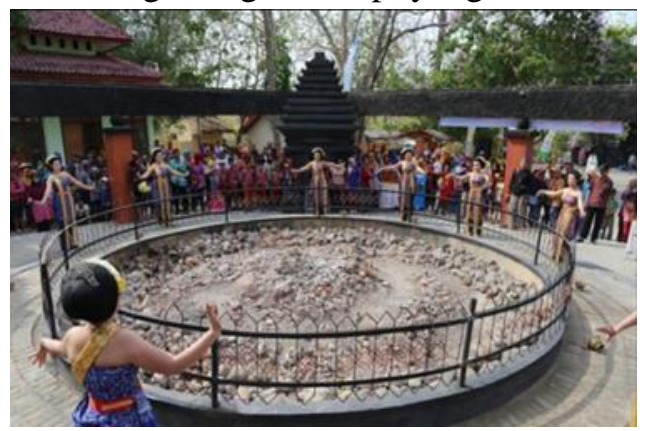

Gambar 1. Para waranggono menari mengelilingi bara api

Prosesi upacara adat wisuda waranggono tidak berlangsung lama hanya membutuhkan waktu beberapa jam saja. Seorang waranggono yang ditemani oleh sesepuh setempat dan juga petugas dari Dinas Kebudayaan dan Pariwisata kemudian menari-nari mengelilingi bara api yang ada di Wisata Kayangan Api. Para waranggono harus menari mengelilingi bara api sebanyak tujuh kali, dipilihnya 
angka tujuh karena dipercaya tujuh adalah angka keberuntungan yang akan mendapat pertolongan dari Yang Maha Kuasa. Tidak menutup kemungkinan peran masyarakat setempat juga dibutuhkan karena dapat menambah wawasan masyarakat tentang upacara adat ini selain itu masyarakat juga dapat menikmati prosesi upacara adat tersebut.

Seluruh prosesi dilaksanakan dengan hikmat dan sakral oleh waranggono yang ingin disahkan, mereka berharap jika mengikuti prosesi upacara adat wisuda waranggono mereka akan mendapatkan berkah dan mendapatkan rejeki yang melimpah saat mengikuti pertunjukan tayub di berbagai daerah. Waranggono menganggap bahwa upacara adat wisuda waranggono sangat penting dilakukan karena mereka percaya jika terdapat berkah tersendiri jika mereka melakukan upacara adat ini. Namun terdapat waranggono yang tidak mempercayai hal tersebut, ini menyangkut kepercayaan masing-masing waranggono.

Upacara adat wisuda waranggono mempunyai beberapa ritual atau piranti yang dibutuhkan, setiap ritual dan juga piranti memiliki nilai-nilai budaya, seperti

a. Puasa, setiap waranggono sebelum mengikuti upacara adat wisuda harus melakukan puasa satu hari satu malam. Puasa ini mempunyai makna agar para waranggono dapat menahan hawa nafsu dan juga penguatan batin pada saat sebelum melakukan kegiatan upacara adat wisuda waranggono.

b. Siraman, Terdapat ritual siraman sebelum upacara adat wisuda waranggono dilakukan. Siraman yang memiliki makna agar para waranggnono dapat membersihkan jasmani maupun rohani sebelum mereka mengikuti upacara.

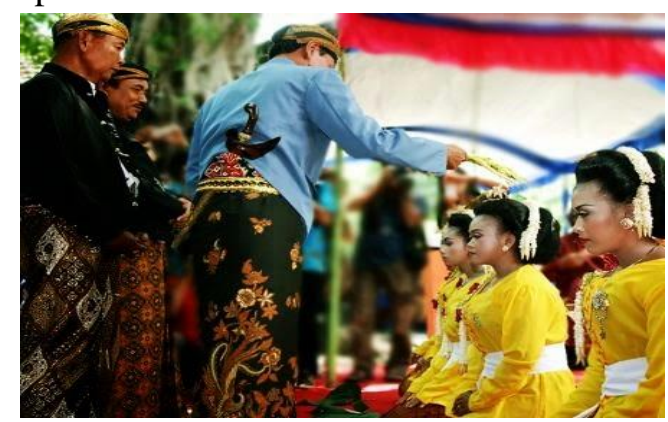

Gambar 2. Sesepuh menyirami para waranggono yang diwisuda

c. Pakaian adat Jawa, dalam upacara adat wisuda waranggono para waranggono menggunakan pakaian adat jawa yang mempunyai makna bahwa seorang waranggono akan terlihat anggun jika menggunakan pakaian kebaya, dan juga pakaian kebaya merupakan pakaian yang termasuk sakral dalam masyarakat Jawa.

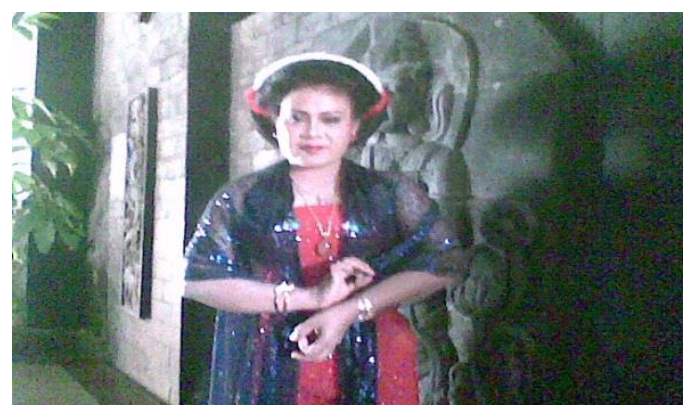

Gambar 3. Waranggono berpakaian adat Jawa

d. Tarian, dalam prosesi upacara adat wisuda waranggono terdapat gerakan di setiap tarian, dan setiap gerakan. Bila seseorang waranggono merentangkan tangan ke depan dengan telapak tangan terbuka dan tangan kiri ditutupkan ke perut maka mempunyai makna menghimbau datangnya rejeki atau bantuan kerja sama untuk keberuntungan kepadanya. 
e. Upacara adat wisuda waranggono juga membutuhkan dupa, masyarakat Jawa percaya bahwa penggunaan dupa dalam upacara adat dapat mengusir roh jahat yang dapat mengganggu dalam kegiatan upacara.

f. Bunga tujuh rupa, masyarakat Jawa percaya bahwa bunga tujuh rupa mempunyai makna sendiri-sendiri, seperti bunga mawar merah yang bermakna kelahiran diri manusia ke dunia, bunga mawar putih yaitu ketentraman, sejahtera dan damai.

Sumber pembelajaran sejarah menurut Hermanu Joebagio (dalam Gurvey dkk, 2015:ix) adalah proses internalisasi nilai-nilai peristiwa masa lalu, berupa asal-usul, silsilah, pengalaman kolektif, dan keteladanan pelaku sejarah. Pembelajaran itu dirancang untuk membentuk pribadi yang arif dan bijaksana, karena itu pembelajaran sejarah menuntut desain yang akan menghasilkan kualitas output yang meliputi pemahaman peristiwa sejarah bangsa, meneladani kearifan dan sikap bijak pelaku sejarah. Pembelajaran sejarah yang baik adalah pembelajaran yang mampu menumbuhkan kemampuan siswa melakukan konstruksi kondisi masa sekarang dengan mengkaitkan atau melihat masa masa lalu yang menjadi basis topik pembelajaran sejarah. Kemampuan melakukan konstruksi ini harus dikemukakan secara kuat agar pembelajaran tidak terjerumus dalam pembelajaran yang bersifat konservatif. Kontekstualitas sejarah harus kuat mengemuka dan berbasis pada pengalaman pribadi para siswa. Apalagi sejarah tidak akan terlepas dari konsep waktu, kontinyuitas dan perubahan (Subakti, 2010:67).

Upacara adat wisuda waranggono merupakan tradisi dilakukan oleh para waranggono, mereka tidak melupakan tradisi yang sudah ada sejak zaman dulu. Dalam upacara ini terkandung banyak sekali hal-hal yang dapat digunakan sebagai sumber pembelajaran sejarah yakni upacara adat wisuda waranggono merupakan warisan budaya sekaligus peninggalan sejarah yang harus dilestarikan oleh generasi muda masa kini, kebanyakan generasi muda masa kini kurang peduli dan memahami kebudayaan atau tradisi lokal sehingga jika tidak dijadikan materi tambahan di sekolah maka upacara adat wisuda waranggono akan tergantikan dengan kebudayaan modern yang sudah banyak menjalar di kalangan generasi penerus pada masa kini.

Upacara adat wisuda waranggono dapat dijadikan sebagai sumber pembelajaran sejarah di sekolah, dalam pembelajaran sejarah guru dapat menggunakan upacara adat wisuda waranggono sebagai contoh agar proses pembelajaran sejarah di dalam kelas tidak terkesan monoton. Peristiwaperistiwa seperti upacara adat, mitos, legenda, dongeng dan juga nyanyian rakyat tidak lepas dari budaya yang telah lalu yang terjadi pada masa pra aksara, seperti halnya upacara adat yang merupakan suatu adat atau kebiasaan masyarakat yang dilakukan sebagai wujud bentuk rasa syukur kepada Tuhan Yang Maha Esa. Nilai-nilai upacara adat wisuda waranggono masuk dalam Standart Kompetensi 1. Memahami prinsip dasar ilmu sejarah dengan KD 1.2 mendeskripsikan tradisi sejarah dalam masyarakat Indonesia masa pra-aksara dan masa aksara. Materi tersebut masuk dalam materi SMA kelas X semester I.

\section{Simpulan}

Berdasarkan paparan data, temuan penelitian dan pembahasan yang dijelaskan sebelumnya maka dapat disimpulkan bahwa prosesi upacara adat wisuda waranggono dilaksanakan pada bulan syuro dan tidak berlangsung lama hanya membutuhkan beberapa jam saja, karena para waranggono yang ditemani oleh sesepuh setempat dan juga dari Dinas Pemerintahan Kabupaten Bojonegoro hanya menari mengelilingi bara api sebanyak tujuh kali sambil menaburkan bunga tujuh rupa ke dalam bara api yang ada di wisata Kayangan Api Bojonegoro.

Upacara adat wisuda waranggono mempunyai nilai-nilai budaya yang terkandung yaitu sebagai wujud rasa syukur waranggono kepada Tuhan YME dan terdapat harapan tersendiri jika 
mengikuti upacara adat ini, harapan yang dimaksud adalah dapat mendapakan berkah dan juga rezeki yang melimpah jika nantinya menjadi seorang waranggono, selain itu mengajarkan kita dan juga masyarakat agar tetap melestarikan warisan budaya leluhur, menjaga tali silaturahmi antar waranggono, dan selalu mengajarkan kita dalam hal sosial, seperti gotong royong agar upacara adat wisuda waranggono berjalan dengan lancar.

Setiap upacara adat pasti memiliki nilai-nilai yang dapat dijadikan sebagai sumber pembelajaran sejarah. Guru dapat memanfaatkan upacara adat wisuda waranggono sebagai contoh dalam materi pembelajaran di sekolah-sekolah yang masuk dalam Standart Kompetensi 1. Memahami prinsip dasar ilmu sejarah dengan KD 1.2 mendiskripsikan tradisi sejarah dalam masyarakat Indonesia masa a di kelas III SDN 01 Manguharjo Kota Madiun.

\section{DAFTAR PUSTAKA}

Hanif, M., (2016), Kesenian Dongkrek (Studi Nilai Budaya dan Potensinya Sebagai Sumber Pendidikan Karakter), Gulawentah: Jurnal Studi Sosial.2(2),132-141

Herawati, N. (2009). Kesenian Tradisional Jawa. Klaten: Saka Mitra Kompetensi

Kochhar, S.K. ( 2008). Pembelajaran Sejarah Teaching of History. Jakarta: PT. Gramedia

Koentjaraningrat. (2009). Pengantar Ilmu Antropologi. Jakarta: Rineka Cipta

Lisbjanto, H. (2013). Wayang. Yogyakarta: Graha Ilmu

Purwadi. (2005). Upacara Tradisional Jawa. Yogyakarta: Pustaka Pelajar

Setiadi, E.M., dkk. (2007). Ilmu Sosial \& Budaya Dasar. Jakarta: Kencana Prenada Media Grup

Strauss, A., dan Corbin, J. (2009). Dasar-dasar Penelitian Kualitatif. Terjemahan oleh Muhammad Shodiq dan Imam Muttaqien. Yogyakarta: Pustaka Pelajar.

Subakti, Y.R. (2010). Paradigma Pembelajaran Sejarah Berbasis Kontruktivisme dalam SPPS, 24(1). 